\title{
Storage Stability, Gastrointestinal Release and Sensory Properties of Cookies Incorporated with Protein-based Moringa oleifera Leaf Extract microcapsule
}

Thammarat Kaewmaanee* and Airouyuwa Osamede Jennifer*

Department of Food Sciences and Nutrition, Faculty of Science and Technology, Prince of Songkla University, Pattani Campus, Pattani 94000, Thailand

*Corresponding authors.E-mail: airouyuwa2016@gmail.com; thammarat.k @ psu.ac.th

https://doi.org/10.12982/CMUJNS.2020.0009

Received: January 28, 2019

Revised: May 21, 2019

Accepted: June 7, 2019

\begin{abstract}
Moringa oleifera leaves have been known for the numerous nutritional and health benefits. In this study, the bioactive compounds present in $M$. oleifera leaf extract were extracted and encapsulated in soy protein isolate (SPI) and pea protein isolate (PPI). The M. oleifera microcapsules (MM) produced were incorporated in cookies on replacement basis at $2.5 \%, 5 \%$ and $10 \%(w / w)$, respectively with wheat flour. Total polyphenolic contents (TPC) of M. oleifera microcapsules with soy protein isolate (MM-SPI) cookies were 0.72, 0.89 and $1.11 \mathrm{mg}$ GAE/g at $2.5 \%$, 5\% and 10\%, respectively and the TPC for M. oleifera microcapsules with pea protein isolate (MM-PPI) cookies were $0.74,0.84$ and $0.93 \mathrm{mg} \mathrm{GAE} / \mathrm{g}$ at $2.5 \%, 5 \%$, and $10 \%$, respectively. The antioxidant scavenging properties (DPPH) of incorporated cookies for MM-SPI cookies were 0.70, 0.84 and $1.22 \mathrm{mg} \mathrm{TE} / \mathrm{g}$ at $2.5 \%, 5 \%$ and $10 \%$, respectively and MM-PPI cookies were $0.43,0.52$ and $0.63 \mathrm{mg} \mathrm{TE} / \mathrm{g}$ at $2.5 \%$, $5 \%$ and $10 \%$, respectively. The storage stability of MM cookies showed slight levels of degradation in the TPC and the percentage TPC retained after 90 days storage were $96.84 \%, 80.65 \%$ and $49.26 \%$ for cookies with $5 \%$ MM-SPI, 5\% MM-PPI and 0\% MM cookies, respectively. The gastrointestinal stability of the MM cookies showed a higher released rate at the intestinal system. The MM were able to mask M. oleifera greenish colouration, although at $10 \%$ incorporation of MM in cookies; the beany flavour of SPI and PPI were intense, which led to low sensory evaluation scores.
\end{abstract}


Keywords: Moringa oleifera, Microencapsulation, Soy protein isolate, Pea protein isolate, Cookies, Total polyphenolic content

\section{INTRODUCTION}

In recent time, due to the advent of chronic diseases affecting the nations of the world consumers no longer need foods with basic nutritional benefits. Hence the need for developing food products with optimal health benefits, such food products are rich in bioactive compounds which contains anti-inflammatory, antidiabetic, anticancer and antioxidant properties. In addition, these food products could act as a better substitute for food supplements regarding its efficiency in bioactive compounds, consumption, safety, delivery, and bioavailability (Tumbas et al., 2016).

Moringa oleifera is an Indian local medicinal herb, which was first discovered from 'Sub-Himalayan tracts of Indian'. It is well known in the tropics and subtropical regions of the world (Ramachandran et al., 1980). M. oleifera has gained importance in the area of functional food ingredients due to it nutritional and health-promoting attributes. According to Kasolo et al. (2010), M. oleifera leaves contains numerous essential nutrients, which includes, amino acids, vitamins, $\beta$-carotene, minerals, and several polyphenolics as well as antioxidants, anti-inflammatory, omega- 3 and omega- 6 fatty acids. The extract of M. oleifera leaves contains high amount of polyphenolic contents which has high antioxidant properties against free radicals, preventing oxidative damage to biomolecules and enables adequate defence from its damage (Sarwat et al., 2012). M. oleifera leaves have slightly bitter taste and its green colour limit its utilisation as functional food ingredient. However, bioactive compounds present in leafy vegetables like the polyphenols are not stable during food processing, storage and along the intestinal tract. The above limitation could lead to a reduction of its potential health benefit (Fang and Bhandari, 2010). To avoid this limitation, ensure stability, palatability and retention of its essential properties during processing, storage and consumption; there is the need for microencapsulation of M. oleifera leaf extract.

Microencapsulation is a method by which droplet size and tiny particles are bounded by a polymer wall material, or are enclosed in a homogeneous or heterogeneous matrix, to form a micro size capsule (Gharsallaoui et al., 2007). It is the entrapment of a gaseous, liquid, or a solid substance within another substance in a very small microcapsule. The core materials are mainly bioactive compounds, which gradually diffused through the capsule walls, ensuring a controlled released under the desired conditions (Fang and Bhandari, 2010). Microencapsulation preserves bioactive constituents and ensures better handling properties. It provides barriers against oxygen, light and temperature. It also masks unpleasant taste and colour. Spray-drying technique is a method of microencapsulation. It is an uninterrupted transformation of feed from a fluid 
state into dried particles produced by spraying the feed fluid into a hot drying chamber. It is a less expensive industrial process which is widely utilised for the encapsulation of fragrances, oils, bioactive compounds and flavours (Desai and Park, 2005).

Researches have been carried out on the interactions between protein and polyphenols; the binding is mainly non-covalent hydrophobic interaction which may later be stabilised by hydrogen bonding (Tumbas et al., 2016). Jakobek (2015) confirms that the interactions between proteins and polyphenol could masked polyphenol and their antioxidant activity. He also suggested the possibility of proteins-polyphenol interactions, could enable proteins to act as a carrier of polyphenols and prevent it from oxidation through the gastrointestinal tracts; this further suggests that proteins are good wall materials for polyphenols. Furthermore, carbohydrate wall materials are mainly used to encapsulate food grade products because of their low viscosity and high film forming attributes. However, carbohydrates possess low interfacial properties and must be modified in order improve their superficial activity (Kanakdande et al., 2007). Whereas, proteins are good amphiphilic molecules with film-forming and emulsifying attributes (Encina et al., 2016). Their structural and chemical characteristics makes them suitable in delivery of bioactive ingredients. Nevertheless, only few proteins have been utilised as wall materials for the encapsulation of bioactive ingredients, and to a lesser extent protein from plant sources (Li and Tang, 2013). Soybeans contain essential fractions $(35-40 \%)$ of proteins they are mostly conglycin and glycinin (50-90\% of total proteins) (Ruiz-Henestrosa et al., 2007). Both isolated and purified soy proteins possesses a good physiochemical, functional attribute, emulsifying properties, particularly gel forming, and surfactant (Gu et al., 2009). Soy protein isolate (SPI) can be used as an individual coating material but can also be mixed with polysaccharides (Augustin et al., 2006). Pea seed extracts are utilised as pea proteins (Koyoro and Powers, 1987). Pea proteins gotten from grains have notable gel-forming (Raymundo et al., 2005) and emulsifying properties (Akintayo et al., 1999). However, literature on microencapsulation uses pea protein isolate (PPI) in mixtures with polysaccharides (Ducel et al., 2004; Gharsallaoui et al., 2007). Protein/ polysaccharide interactions give a vital properties to pea proteins without enzymatic or chemical modification, especially foaming solubility and surfactant properties (Liu et al., 2010). Although in this study, only PPI and SPI were utilised as wall materials for encapsulation of $M$. oleifera leaf extract to see its effectiveness.

Cookies offer an important supplementation vehicle for nutritionally developed products since they are generally accepted and consumed by all age grades. They are one of the most common and ready to eat food with low price. Hence, nutritional enrichment of cookies is of great importance. Studies have shown that the fortification of $M$. oleifera leaves in food as value-added products (Kar et al, 2013; Oyeyinka and Oyeyinka, 2018). According to Sengev et al. 
(2013), the replacement of $M$. oleifera leaf powder in bread increases the nutritional composition of bread, but it is not a good substitute with wheat flour due to it poor physical characteristics and low sensory attributes. Also, studies from Kar et al. (2013) showed M. oleifera leaves incorporated in cookies had very low sensory evaluation dues to it off flavour and slightly bitter taste. To overcome the above limitations, M. oleifera leaf extract were encapsulated with SPI and PPI and incorporated in cookies. This will enhance the physical characteristics of cookies; increase it sensory attributes, storage stability and control release of the bioactive compounds in the gastrointestinal tract.

The study was aimed to evaluate the possibility to developed functional cookies, enriched with M. oleifera leaf extract encapsulated in SPI and PPI. In addition, to evaluate the sensory properties of cookies, storage stability and gastrointestinal release profile of the bioactive compounds present in the fortified cookies.

\section{MATERIALS AND METHODS}

The leaves of $M$. oleifera were obtained from a farm in Yarin distrist, Pattani Province, Thailand. M. oleifera leaves were washed with tap water to eliminate sand and other contaminants. The leaves were freeze-dried using a freeze dryer (FD8-CoolSafe Advanced, Scan Vac A/S, Demark) later crushed with a food processor and sieved with 250 micro mesh in order to obtain a fine powder. The fine $M$. oleifera leaf powder was stored in an airtight polyethylene pouch at $4^{\circ} \mathrm{C}$ before further analysis.

\section{Preparation of Moringa oleifera extract (MLE)}

Moringa oleifera leaf extract (MLE) was prepared by macerated $5 \mathrm{~g}$ of M. oleifera leaf powder in $250 \mathrm{~mL}$ of $80 \%$ ethanol in an erlenmeyer flask and corked. The solution was placed on a magnetic stirrer for 24 hours and sieved with Whatman No.1 filter paper. The extraction process was repeated twice, the filtrate was concentrated using rotary evaprator and vacuum centrifuge evaporator (R1).

\section{Preparation of Moringa oleifera microcapsule (MM)}

Moringa oleifera microcapsules were produced by spray drying techniques with two different plant proteins as wall materials. The bioactive compounds present in MLE were encapsulated in pea protein isolate (PPI), and soy proteins isolate (SPI) at an inlet air temperature of $180^{\circ} \mathrm{C}$, the core: wall material ratio was $1: 4(\mathrm{w} / \mathrm{w})$, respectively. The wall materials were prepared by dissolving $19.8 \mathrm{~g}$ protein in distilled water and placed in a water bath for 2 hours at $50^{\circ} \mathrm{C}$ and $100 \mathrm{rpm} .100 \mathrm{~mL}$ of M. oleifera leaf extract solution $(0.022 \mathrm{~g}$ extract $/ \mathrm{mL}$ ) was added to the protein solution. The mixture was homogenised at $16,000 \mathrm{rpm}$ for $10 \mathrm{~min}$ (Ton et al., 2015) and fed into the spray dry chamber with a peristatic pump at a rate of $23 \mathrm{~mL} / \mathrm{min}$, the inlet air and outlet air temperature 
were $180^{\circ} \mathrm{C}$ and $75 \pm 5^{\circ} \mathrm{C}$, respectively. The air pressure was 2.0 bar atomiser and a nozzle diameter of $1.0 \mathrm{~mm}$. M. oleifera microcapsules $(\mathrm{MM})$ produced were stored in an airtight polyethylene pouch at $-20^{\circ} \mathrm{C}$ for further analysis.

\section{Preparations of MM cookies}

On replacement basis, a combination of wheat flour with MM-SPI and MM-PPI powder containing $2.5 \%, 5 \%$, and $10 \% \mathrm{w} / \mathrm{w}$, and control cookies $(0 \%$ MM cookies) was prepared, respectively. The cookies were prepared according to Gisslen (2015) with slight modifications. All the dried ingredients were sieved; butter (12.5 g), shortening (37.5 g) and icing sugar (30 g), were mixed with a mixer at low speed for about $3 \mathrm{~min}$. $\mathrm{NaCl}(0.8 \mathrm{~g}), \mathrm{NH}_{4} \mathrm{HCO}_{3}(0.1 \mathrm{~g})$ were mixed with egg $(9.5 \mathrm{~g})$ and added to the creamed sugar-butter mixture and mixed for an additional $3 \mathrm{~min}$. Thereafter, the wheat flour and encapsulated powder were added and continue mixing for about 5 min at medium speed. After mixing, each dough was rolled into a polyethylene bag and chilled for 2 hours in the refrigerator. The dough was cut and baked in an oven at $180 \pm 10^{\circ} \mathrm{C}$ for about 15 min and cooled for about $30 \mathrm{~min}$ on a sterilised wired rack. The cookies were packed in high-density polypropylene pouches and stored in an airtight container at room temperature.

\section{Analysis of total polyphenolic content (TPC) and DPPH activity}

The total polyphenol content (TPC) and DPPH activity was determined on both dough and cookies. To obtain the extracts for analysis, $200 \mathrm{mg}$ of each dough and cookies sample was extracted in a mixture of $1 \mathrm{~mL}$ acetone, $1 \mathrm{~mL}$ of methanol, acetic acid and water mixture at a ratio of (50:8:42). The solution was stirred with a vortex stirrer for $1 \mathrm{~min}$ and centrifuged at 6,000 rpm for $5 \mathrm{~min}$. In the dough samples, the solutions were homogenised at 11,000 rpm for $2 \mathrm{~min}$ before centrifugation. The supernatant was filtered by Whatman filter paper No 1. The total phenolic content of dough and cookies extracts were analysed using the folin-Ciocalteu method by Singleton et al. (1999), while antioxidant activity (DPPH) of each sample was analysed using spectrophotometer by the method of Payet et al. (2005). The result was expressed in mg Gallic acid equivalents per $\mathrm{g}$ cookies (mg GAE/g cookies) and mg Trotox equivalent per $\mathrm{g}$ cookies (mg TE/g cookies), respectively.

\section{Storage stability}

The storage stability of MM cookies was carried out, based on its sensory evaluation scores. About $50 \mathrm{~g}$ of 5\% MM-SPI, 5\% MM-PPI and 0\% MM cookies were selected for storage. The cookies were stored in high-density polypropylene pouches at room temperature for 90 days, the TPC in cookies was analysed every two weeks, in order to evaluate the rate of degradation of TPC with time. 


\section{Gastrointestinal release profile}

The gastrointestinal released profile of 5\% MM-SPI, 5\% MM-PPI and 0\% MM cookies were analysed by in vitro analysis, simulating gastrointestinal fluids; the simulation of gastric and intestinal fluid system were carried out by (Chiu et al. 2007; Paramera et al. 2011; Zheng et al. 2011). The gastric fluid simulation at $\mathrm{pH} 2.0$ consist of $0.1 \mathrm{M}$ Citric acid solution and $0.3 \%$ pepsin enzyme. The intestinal fluid system at $\mathrm{pH} 8.0$ consist of di-sodium phosphate buffer (Chiu et al., 2007), and $0.1 \%$ pancreatic enzyme (Paramera et al., 2011)

$0.1 \mathrm{~g}$ of $5 \%$ MM-SPI and MM-PPI cookies and $0 \%$ MM cookies were added to $20 \mathrm{~mL}$ of each solution (simulated gastric and intestinal fluid). The solutions were continuously stirred in a water bath of $100 \mathrm{rpm}$ at $37{ }^{\circ} \mathrm{C} .1 .5 \mathrm{~mL}$ aliquot of the solutions were collected at 0, 30, 60, 120, 180 and $240 \mathrm{~min}$, respectively. The solutions were centrifuged for $15 \mathrm{~min}$, at $3,420 \mathrm{~g}$ and the supernatants were used for the determination of TPC. The sample aliquot taking from the water bath was replaced by the same quantity of the respective solutions (Belak-Cvitanovi et al., 2011).

\section{Colour analysis}

The surface colour of the cookies was determined in 10 replicates after 24 hours of baking. CIE lab colour coordinate ( $L^{*}$; lightness, $a^{*}$; redness to greenness and $b^{*}$; yellowness to blueness) were evaluated using the colour meter (Mini Scan XE Plus, Model 45/0S, Hunter Associate Laboratory Inc., U.S.A.). The equipment was operated in reflectance specular included mode (RSIN, area view $=19.812 \mathrm{~mm}$, illuminant $=$ D65/10) and a white tile was used in calibration before taken measurements. The results were expressed in the mean value of all sample replicates.

\section{Sensory analysis}

A panel comprising of 30-trained panellist from the Faculty of Science and Technology, Prince of Songkla University, Pattani Campus performed a sensory evaluation attributes on the cookies. The panellist evaluated each freshly baked cookies attributes based on odour, crispiness, appearance, flavour, colour and overall acceptability, by applying nine-point hedonic scale. The data contained on the sensory performance were indicated as $9=$ like extremely, $8=$ like very much $7=$ like moderately $6=$ like slightly, $5=$ neither like or dislike, $4=$ dislike slightly, $3=$ dislike, $2=$ dislike very much, $1=$ dislike extremely.

The cookies were coded with three-digit random numbers and served to the panellists on a white plate. The analysis was performed in a sensory laboratory room; a partition closet and brightened with fluorescence lights. The panellists rinsed their mouth with water after eating each sample.

\section{Statistical Analysis}

All experiments were carried out by completely randomised design (CRD). The data were subjected to analysis of variance (ANOVA). Duncan's multiple 
range tests with a confidence interval of $0.5 \%(P<0.05)$. Statistical analysis was performed using the Statistical Package for Social Science (SPSS for Windows; SPSS Inc.).

\section{RESULT}

\section{Total phenolic content (TPC) and DPPH activity on cookie dough and baked MM cookies}

In this study, the TPC and DPPH activities from M. oleifera leaf powder extracted with $80 \%$ ethanol were $26.45 \pm 0.85 \mathrm{mg}$ GAE/g powder and $45.75 \pm \mathrm{mg}$ TE/g powder. The resulting TPC and DPPH activities of MM-SPI was $11.96 \pm$ $0.77 \mathrm{mg} \mathrm{GAE} / \mathrm{g}$ and $8.12 \pm 0.53 \mathrm{mg}$ TE$/ \mathrm{g}$, and in MM-PPI was $8.81 \pm 0.30 \mathrm{mg}$ $\mathrm{GAE} / \mathrm{g}$ and $4.45 \pm 0.19 \mathrm{mg} \mathrm{TE} / \mathrm{g}$, respectively. The result of microencapsulation of MM-SPI and MM-PPI showed the ability of protein to bind and interact with polyphenols. The result also showed that the interaction between the wall materials and the bioactive compounds present in MLE varies in MM produced.

Table 1 shows the TPC and DPPH activities of the dough and baked cookies incorporated with MM-SPI and MM-PPI at different formulations. From the results, it was observed that the TPC and DPPH activity of the respective cookies were susceptible to thermal degradation during the process of baking. It was also observed that MM-SPI cookies have the highest rate of TPC and DPPH activities when compared with MM-PPI cookies and 0\% had the least TPC and DPPH activities.

Table 1. TPC and DPPH activity of cookies incorporated with MM-SPI and MM-PPI at different concentration.

\begin{tabular}{ccccc}
\hline $\begin{array}{c}\text { MM } \\
\text { concentrations } \\
(\%, \text { w/w })\end{array}$ & \multicolumn{2}{c}{$\begin{array}{c}\text { TPC } \\
(\mathbf{m g ~ G A E} / \mathbf{g})\end{array}$} & \multicolumn{2}{c}{$\begin{array}{c}\text { DPPH scavenging activity } \\
(\mathbf{m g} \text { TE/g) }\end{array}$} \\
\cline { 2 - 5 } & $\begin{array}{c}\text { Dough } \\
\text { cookies }\end{array}$ & Baked cookies & Dough cookies & Baked cookies \\
\hline $0 \%(\mathrm{MM})$ & $0.81 \pm 0.05^{\mathrm{Ga}}$ & $0.68 \pm 0.12^{\mathrm{fB}}$ & $0.46 \pm 0.01^{\mathrm{Ga}}$ & $0.32 \pm 0.052^{\mathrm{fB}}$ \\
\hline $2.5 \%$ MM-SPI & $1.07 \pm 0.05^{\mathrm{Da}}$ & $0.72 \pm 0.13^{\mathrm{eB}}$ & $0.98 \pm 0.05^{\mathrm{Ca}}$ & $0.70 \pm 0.01^{\mathrm{cB}}$ \\
$5 \% \mathrm{MM}-\mathrm{SPI}$ & $1.19 \pm 0.03^{\mathrm{Ba}}$ & $0.89 \pm 0.89^{\mathrm{cB}}$ & $1.36 \pm 0.15^{\mathrm{Ba}}$ & $0.84 \pm 0.03^{\mathrm{bB}}$ \\
$10 \% \mathrm{MM}-\mathrm{SPI}$ & $1.47 \pm 0.11^{\mathrm{Aa}}$ & $1.11 \pm 0.07^{\mathrm{aB}}$ & $1.81 \pm 0.01^{\mathrm{Aa}}$ & $1.22 \pm 0.81^{\mathrm{aB}}$ \\
\hline $2.5 \% \mathrm{MM}-\mathrm{PPI}$ & $0.87 \pm 0.06^{\mathrm{Fa}}$ & $0.74 \pm 0.06^{\mathrm{eB}}$ & $0.58 \pm 0.05^{\mathrm{Fa}}$ & $0.43 \pm 0.01^{\mathrm{eB}}$ \\
$5 \% \mathrm{MM}-\mathrm{PPI}$ & $1.02 \pm 0.10^{\mathrm{Ea}}$ & $0.84 \pm 0.31^{\mathrm{dB}}$ & $0.69 \pm 0.67^{\mathrm{Ea}}$ & $0.51 \pm 0.22^{\mathrm{dB}}$ \\
$10 \% \mathrm{MM}-\mathrm{PPI}$ & $1.16 \pm 0.03^{\mathrm{Ca}}$ & $0.93 \pm 0.19^{\mathrm{bB}}$ & $0.85 \pm 0.26^{\mathrm{Da}}$ & $0.68 \pm 0.23^{\mathrm{cB}}$
\end{tabular}

Note: Data were presented mean $\pm \mathrm{SD}(\mathrm{n}=3)$, ${ }^{*}$ Different superscript of small letters within a column shows a significant difference $(P<0.05)$ and different superscript capital letters between row are significantly different for each assay $(P<0.05)$. 


\section{Storage stability}

In the storage stability, three selected samples based on the sensory evaluation were (5\% MM-SPI cookies, 5\% MM-PPI cookies and 0\% MM cookies) were tested for TPC as shown in Figure 1. The packed cookies were stored at room temperature for 12 weeks and analysis of TPC was carried out every two weeks. From the results, the initial concentration of TPC present MMSPI, MM-PPI and 0\% MM cookies were 0.89, 0.87 and $0.68 \mathrm{mg}$ GAE/g, respectively. At the end of 12 weeks, the rates of degradation were 0.89-0.86, 0.87-0.7 and 0.68-0.33 mg GAE/g for MM-SPI, MM-PPI and 0\% MM cookies, respectively.

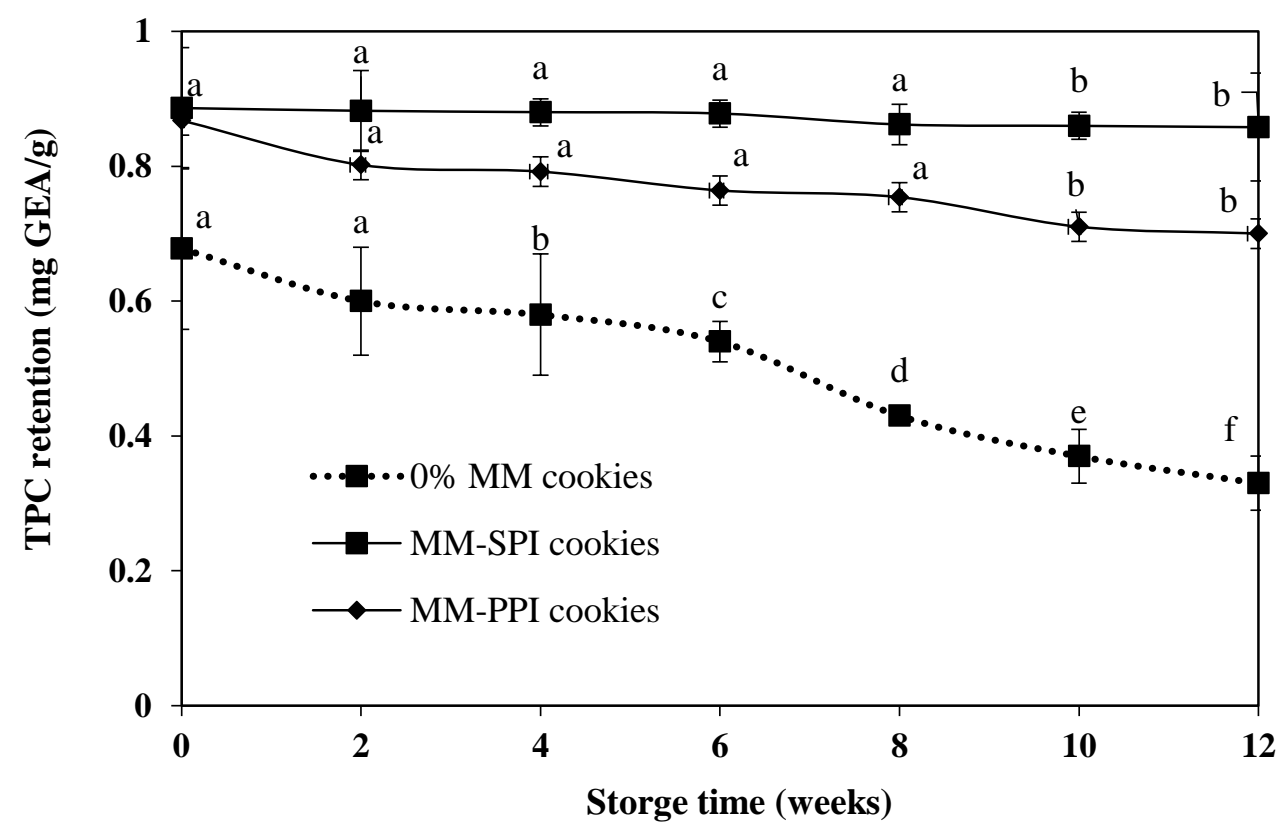

Figure 1.Total phenolic content (TPC) retention in $0 \%$ MM cookies and Moringa oleifera microcapsules (5\% MM) at room temperature for 90 days storage.

\section{Gastrointestinal release profile of $\mathrm{MM}$ cookies}

The gastrointestinal release of TPC of both MM-SPI and MM-PPI cookies were shown in Figure 2. In the gastric simulation with pepsin enzyme at $\mathrm{pH} 2.0$, the rate of release was significantly lower when compared to intestinal stimulation with $\mathrm{pH} 8.0(P<0.05)$. The low level of release at $\mathrm{pH} 2.0$ could because of co-precipitation of phenolics with protein and other constituents at the gastric system (Mc Dougall et al., 2005; Flores et al., 2014). The total amount of TPC released for MM-SPI, MM-PPI and 0\% MM cookies were 0.67, 0.65 and $0.59 \mathrm{mg} \mathrm{GAE} / \mathrm{g}$, respectively after $240 \mathrm{~min}$ of digestion, whereas the amount of TPC released at the intestinal system was $0.78,0.75$ and $0.67 \mathrm{mg} \mathrm{GAE} / \mathrm{g}$ after 240 min of digestion. 

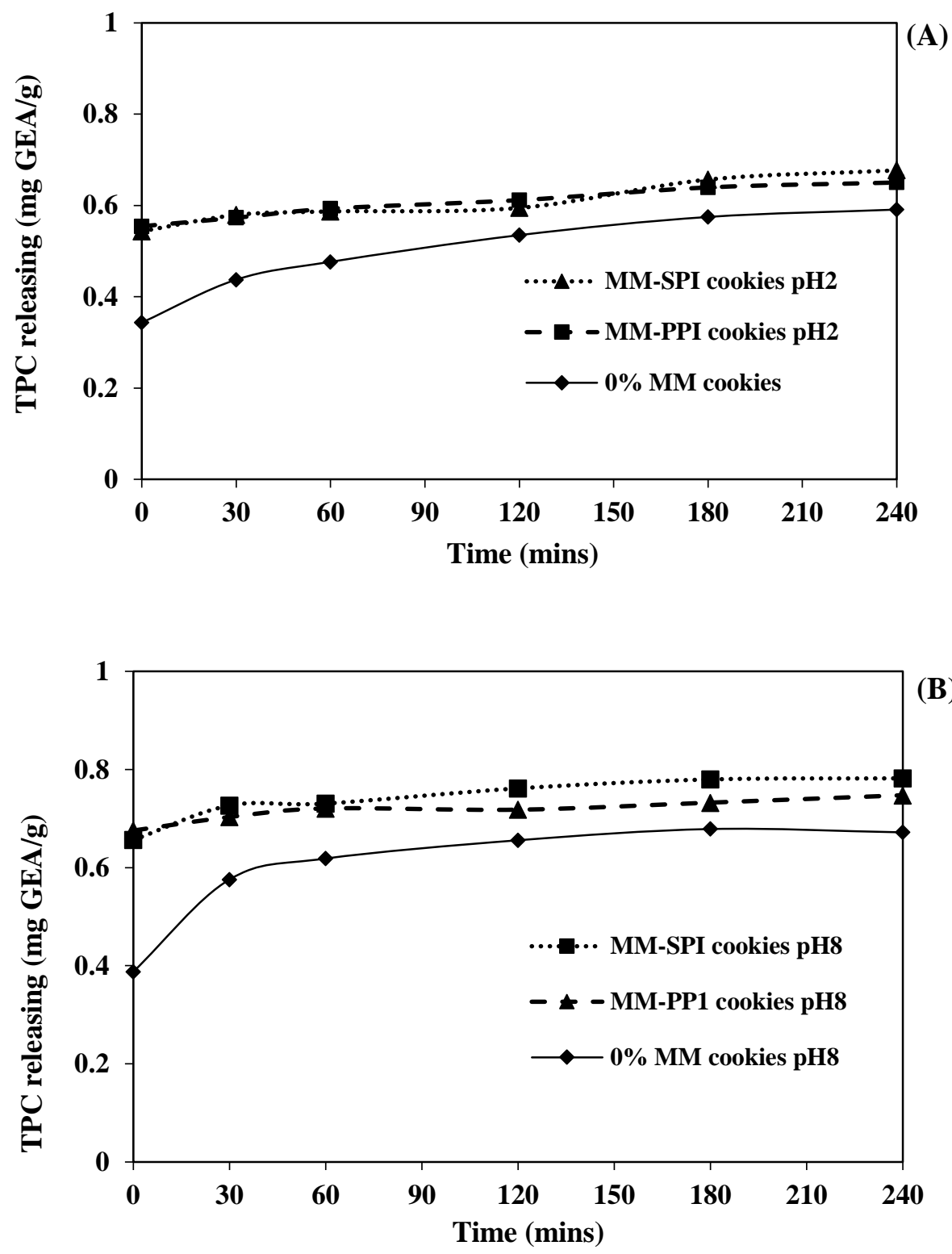

Figure 2. Total phenolic releasing profile in the simulated gastric system (SG) (A) and total phenolic releasing profile in the simulated intestinal system (SI) (B).

\section{Colour}

Cookies colour were evaluated by three main parameters, which includes the $L^{*}, a^{*}$ and $b^{*}$ values. The $L^{*}$ significance the level of lightness, $a^{*}$ significance specifies redness or greenness and $b *$ significance yellowness of the sample. Table 2 shows the results obtained from the colour analysis of MM-SPI and MM-PPI cookies. Cookies with $10 \%$ MM exhibited the least lightness $\left(L^{*}\right)$ and more greenish colourations when compared to other formulations. Similar results were observed in Figure 3, in 10\% MM-SPI and MM-PPI cookies; the 
cookies appearance were darker and also MM-PPI cookies had lower lightness similar to its $L^{*}$ values when compared to MM-SPI cookies.

Table 2. Physical properties of cookies incorporated with MM-SPI and MM-PPI at different concentration.

\begin{tabular}{lccc}
\hline \multirow{2}{*}{$\begin{array}{c}\text { MM } \\
\text { concentrations } \\
(\%, \text { w/w })\end{array}$} & $\boldsymbol{L}^{*}$ & $\boldsymbol{a}^{*}$ & $\boldsymbol{b}^{*}$ \\
\hline $0 \%(\mathrm{MM})$ & $71.78 \pm 0.94^{\mathrm{a}}$ & $71.78 \pm 0.94^{\mathrm{a}}$ & $36.10 \pm 0.22^{\mathrm{b}}$ \\
\hline $2.5 \%$ MM-SPI & $65.86 \pm 0.57^{\mathrm{b}}$ & $65.86 \pm 0.57^{\mathrm{b}}$ & $35.65 \pm 0.25^{\mathrm{c}}$ \\
$5 \%$ MM-SPI & $60.72 \pm 0.030^{\mathrm{d}}$ & $60.72 \pm 0.03^{\mathrm{d}}$ & $35.41 \pm 0.30^{\mathrm{c}}$ \\
$10 \%$ MM-SPI & $54.45 \pm 0.28^{\mathrm{f}}$ & $54.45 \pm 0.28^{\mathrm{f}}$ & $35.55 \pm 0.40^{\mathrm{c}}$ \\
\hline $2.5 \%$ MM-PPI & $62.26 \pm 0.75^{\mathrm{c}}$ & $62.26 \pm 0.75^{\mathrm{c}}$ & $36.08 \pm 0.16^{\mathrm{b}}$ \\
$5 \% \mathrm{MM}-\mathrm{PPI}$ & $56.46 \pm 0.16^{\mathrm{e}}$ & $56.46 \pm 0.16^{\mathrm{e}}$ & $36.96 \pm 0.32^{\mathrm{a}}$ \\
$10 \% \mathrm{MM}-\mathrm{PPI}$ & $47.03 \pm 0.19^{\mathrm{g}}$ & $47.03 \pm 0.19^{\mathrm{g}}$ & $32.06 \pm 0.279^{\mathrm{d}}$ \\
\hline
\end{tabular}

Note: Data were presented mean \pm SD $(n=3)$, Different superscripts within a column are significantly different $(P<0.05)$.
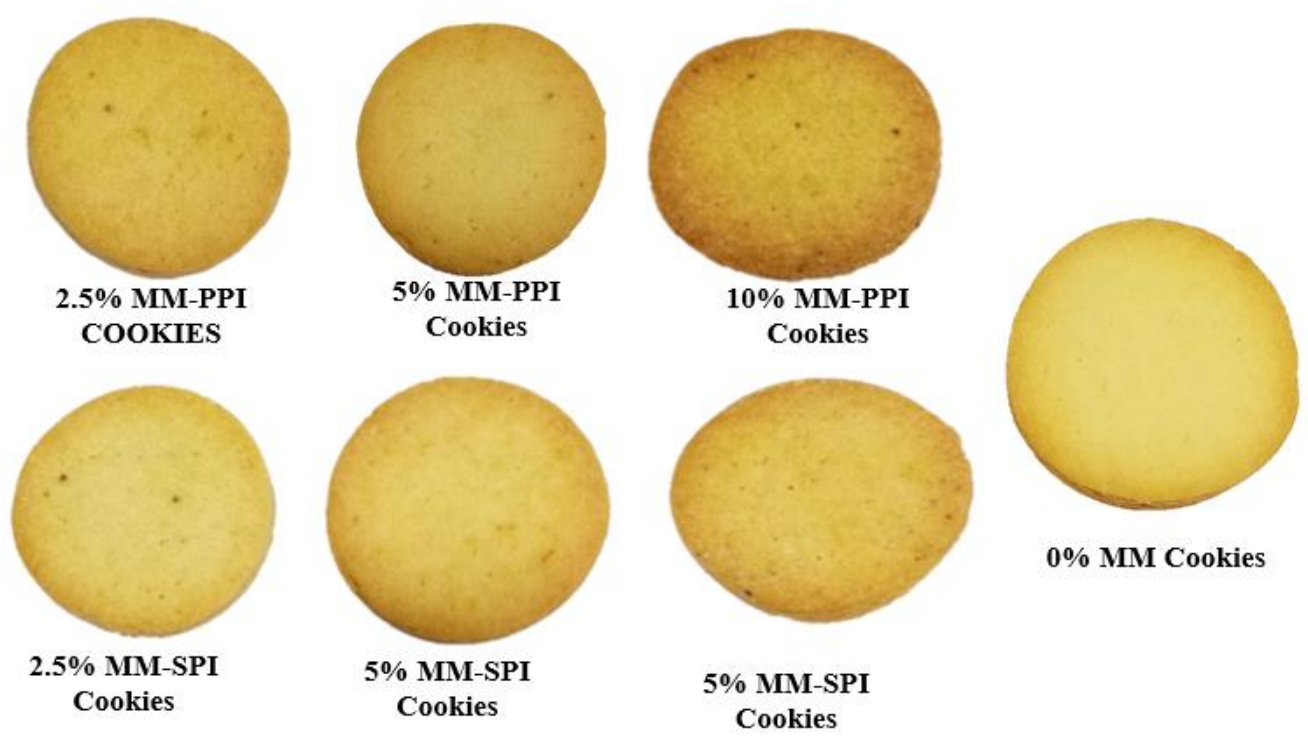

Figure 3. MM-PPI and MM-SPI cookies at different concentrations of MM and control cookies ( $0 \%$ MM cookies).

\section{Sensory properties}

The formulation of new product development needs to consider the sensory evaluation and consumer acceptability. Table 3 showed the results obtained from sensory quality assessment. This analysis was determined to evaluate the consumer acceptability for MM-SPI and MM-PPI cookies. The sensory quality 
of the cookies was rated based on the following attributes: colour, overall acceptability, odour, flavour, appearance, taste and crispiness. Cookies with $10 \%$ incorporation of MM-SPI and MM-PPI had significantly low sensory attributes in all the formulations.

Table 3. Sensory evaluation of control and cookies incorporated with MM-PPI and MM-SPI at different concentration using a 9-point hedonic scale.

\begin{tabular}{cccccccc}
\hline $\begin{array}{c}\text { MM } \\
\text { concentrations } \\
(\%, \text { w/w })\end{array}$ & Colour & Odour & Flavour & Taste & Crispiness & Appearance & $\begin{array}{c}\text { Overall } \\
\text { acceptance }\end{array}$ \\
\cline { 2 - 8 } $0 \%$ MM & $7.50 \pm$ & $6.73 \pm$ & $7.07 \pm$ & $7.96 \pm$ & $7.68 \pm$ & $7.10 \pm$ & $7.13 \pm$ \\
& $1.81^{\mathrm{a}}$ & $1.78^{\mathrm{a}}$ & $1.44^{\mathrm{a}}$ & $1.87^{\mathrm{a}}$ & $1.22^{\mathrm{a}}$ & $1.47^{\mathrm{a}}$ & $1.53^{\mathrm{a}}$ \\
\hline \multirow{2}{*}{$2.5 \%$ MM-PPI } & $7.07 \pm$ & $6.50 \pm$ & $6.20 \pm$ & $6.31 \pm$ & $6.80 \pm$ & $6.60 \pm$ & $6.57 \pm$ \\
& $1.74^{\mathrm{ab}}$ & $1.67^{\mathrm{abc}}$ & $1.54^{\mathrm{ab}}$ & $1.57^{\mathrm{ab}}$ & $1.45^{\mathrm{abc}}$ & $1.33^{\mathrm{ab}}$ & $1.13^{\mathrm{ab}}$ \\
$5 \%$ MM-PPI & $6.90 \pm$ & $5.97 \pm$ & $6.00 \pm$ & $6.33 \pm$ & $6.93 \pm$ & $6.13 \pm$ & $6.37 \pm$ \\
& $1.56^{\mathrm{ab}}$ & $1.67^{\mathrm{abc}}$ & $1.66^{\mathrm{b}}$ & $1.57^{\mathrm{ab}}$ & $1.39^{\mathrm{ab}}$ & $1.38^{\mathrm{ab}}$ & $1.12^{\mathrm{ab}}$ \\
& $6.23 \pm$ & $5.73 \pm$ & $5.53 \pm$ & $5.87 \pm$ & $6.83 \pm$ & $6.07 \pm$ & $6.20 \pm$ \\
& $1.08^{\mathrm{b}}$ & $1.81^{\mathrm{bcd}}$ & $1.87^{\mathrm{bc}}$ & $1.89^{\mathrm{bc}}$ & $1.44^{\mathrm{abc}}$ & $1.57^{\mathrm{b}}$ & $1.56^{\mathrm{b}}$ \\
\hline \multirow{2}{*}{$2.5 \%$ MM-SPI } & $6.66 \pm$ & $6.63 \pm$ & $6.36 \pm$ & $6.60 \pm$ & $6.96 \pm$ & $6.27 \pm$ & $6.87 \pm$ \\
& $1.49^{\mathrm{ab}}$ & $1.47^{\mathrm{ab}}$ & $1.38^{\mathrm{ab}}$ & $1.38^{\mathrm{ab}}$ & $1.35^{\mathrm{ab}}$ & $1.53^{\mathrm{ab}}$ & $1.07^{\mathrm{ab}}$ \\
$5 \%$ MM-SPI & $6.10 \pm$ & $5.60 \pm$ & $5.907 \pm$ & $6.30 \pm$ & $7.10 \pm$ & $6.93 \pm$ & $6.43 \pm$ \\
& $1.67^{\mathrm{b}}$ & $1.59^{\mathrm{cd}}$ & $1.43^{\mathrm{b}}$ & $1.34^{\mathrm{ab}}$ & $1.46^{\mathrm{ab}}$ & $1.64^{\mathrm{b}}$ & $1.10^{\mathrm{ab}}$ \\
$10 \%$ MM-SPI & $4.7 \pm$ & $4.90 \pm$ & $4.90 \pm$ & $5.03 \pm$ & $5.96 \pm$ & $4.97 \pm$ & $5.27 \pm$ \\
& $1.09^{\mathrm{c}}$ & $1.80^{\mathrm{cd}}$ & $1.72^{\mathrm{c}}$ & $1.52^{\mathrm{cd}}$ & $2.17^{\mathrm{cd}}$ & $1.47^{\mathrm{c}}$ & $1.44^{\mathrm{c}}$ \\
\hline
\end{tabular}

Note: Data were presented mean \pm SD ( $\mathrm{n}=30)$, Different superscripts within a column are significantly different $(P<0.05)$.

\section{DISCUSSION}

A significantly higher amount of TPC and DPPH activities was observed in MM-SPI when compared with MM-PPI, this may be due to higher protein content present in SPI than in PPI. The higher the protein content present in the wall materials, the more interactions between the polyphenol present in M. oleifera leaf extract (Tumbas et al., 2016). There was a significant decrease in the TPC and DPPH activity of baked cookies when compared to the dough because of thermal lost at $\left(180^{\circ} \mathrm{C}\right)$, baking temperature that was in line with the report of Zheng et al. (2014). The results from this present study shows that TPC and DPPH scavenging activity was significantly higher $(P<0.05)$ in MM-SPI cookies when compared to MM-PPI cookies. It also indicated that MM-PPI cookies exhibited significantly higher thermal degradation when compared to MM-SPI cookies. This could be due to the higher protein content of SPI shielding the bioactive compounds from degradation during baking processes. Similar 
results were found in the incorporation of sour cherry pomace with soy and whey protein incorporated in cookies. Soy proteins have higher protein content and were able to bind more polyphenolic compounds than whey proteins (Tumbas et al., 2016).

Base on TPC in both 5\% MM-SPI and MM-PPI incorporated cookies, there was no statistical difference $(P<0.05)$ in the storage stability of cookies from $0-8$ weeks storage. There was a statistical difference between week 10 and 12 of cookies storage $(P<0.05)$. In $0 \%$ MM cookies, there was statistical difference in every two weeks of analysis. MM cookies experience a slight level of degradation; the percentage of TPC retained after 12 weeks was $96.84 \%, 80.65 \%$ and $49.26 \%$ for $5 \%$ MM-SPI, 5\% MM-PPI and 0\% MM cookies. The $0 \% \mathrm{MM}$ cookies experienced a higher rate of degradation of TPC, more than 50\% loss after 12 weeks storage. In this study, MM retained more TPC in cookies when compared to $0 \% \mathrm{MM}$ cookies, respectively. MM-SPI cookies have a significantly low rate of degradation; it could be due to the higher proteins content of MM-SPI compared MM-PPI, which forms stronger aggregated network during baking process preventing degradation of polyphenols. That is, lower quantity of protein carrier will have little polyphenol binding site and can be easily degraded when compared to a higher protein carrier (Tumbas et al., 2016).

In the gastrointestinal release profile, it was observed that the rate of TPC was more released at the intestinal system. These results are similar to Flore et al. (2014) and Tumbas et al. (2016). In both experiments, it was observed that when proteins were used as wall materials, the amount of TPC was more released at the intestinal system. The control released of TPC is highly essential; this indicated that the consumption of moringa microcapsules cookies is viable because of the avoidance of loss of bioactive compounds during processing (Belak-Cvitonivi et al., 2011).

The colour of food is a vital quality assessed by consumers before consumption, as the level of MM-SPI and MM-PPI incorporated into cookies increase, the lower the $L *$ value obtained. The addition of more MM decreases the lightness of cookies and there was a significant reduction in the $a^{*}$ value, as the level of MM-SPI and MM-PPI incorporation in cookies increases; it shows that cookies tend to be greenish as more MM were incorporated. The $a^{*}$ value of cookies was related to the level of MM-SPI and MM-PPI incorporated in cookies as seen in Figure 3. The 10\% incorporation of MM-SPI and MM-PPI in cookies had the lowest $a^{*}$ and $b^{*}$ value in all the formulated cookies analysed. However, cookies enriched with MM-SPI tend to show less greenish colouration and more lightness when compared to cookies enriched with MM-PPI; although soy protein isolate possessed a higher $L^{*}$ value (91.70) than pea protein isolate (87.25).

In the sensory evaluation, cookies appearance and colour indicate an essential quality of cookies, as professed by the consumers' eyes. The result obtained in this study indicated a significant difference in cookies at $10 \%$ formulation in both MM-SPI and MM-PPI cookies. The result is also related to 
cookies colour analysis, where the $L^{*}$ value decreased at $10 \%$ formulation (Table 2). Sensory evaluation based on flavour and odour of MM-SPI and MM-PPI cookies had the least score at $10 \%$ formulation; this indicates that higher concentration of MM-SPI and MM-PPI in cookies leads to beany flavour in cookies. Crispiness and taste are essential quality marker; they suggest the mouthfeel, detected by tongue receptors (de Man, 1999). There was no significant difference between 0\% MM, MM-SPI and MM-PPI cookies expect at $10 \%$ incorporation. The result implies that at high concentration of MM-SPI and MMPPI cookies, the texture of the cookies in terms of crispiness and taste was compromised and the panellists were not willing to accept the intense taste and less crispiness of the cookies. In the overall acceptability of cookies, there was no significant difference between cookies, $0 \% \mathrm{MM}$ and the enriched cookies except for $10 \%$ formulations. It implies that microencapsulation of Moringa oleifera leaf extract incorporation in cookies can be preferred in cookies at 5\% concentration. Based on the results of sensory evaluation, cookies with 5\% MM formulation serves as the optimal level for replacement with wheat flour.

\section{CONCLUSION}

Microencapsulation of Moringa oleifera leaf extract in SPI and PPI were able to bind the total phenolic contents; it also enhances the storage stability of TPC in the fortified cookies. The study also showed that TPC in cookies could be absorbed in the intestinal system since more TPC were released at the intestinal system. MM were able to mask Moringa oleifera leaves greenish colouration although, at $10 \%$ formulation, the beany flavour of SPI and PPI were observed by the panelists which led to low sensory evaluation scores.

\section{RECOMMENDATION}

It could be recommended that in order to reduce the beany flavour in $10 \%$ MM cookies, the quantity of wall materials used (SPI and PPI) should be replaced or substituted with a carbohydrate wall material. This will help to reduce the beany flavour of vegetable proteins.

\section{REFERENCES}

Akintayo, E.T., Oshodi, A.A., and Esuoso, K.O. 1999. Effects of $\mathrm{NaCl}$, ionic strength and $\mathrm{pH}$ on the foaming and gelation of pigeon pea (Cajanus cajan) protein concentrates. Food Chemistry. 66(1): 51-56.

Augustin, M.A., Sanguansri, L., and Bode, O. 2006. Maillard reaction products as encapsulants for fish oil powders. Journal of Food Science. 71(2): 25-32. https://doi.org/10.1111/j.1365-2621.2006.tb08893.x 
Belak-Cvitanovi, A., Stojanovi, R., Manojlovi, V., Komes, D., Cindri I.J., Nedovi, V., and Bugarski, B. 2011. Encapsulation of polyphenolic antioxidants from medicinal plant extracts in alginate-chitosan system enhanced with ascorbic acid by electrostatic extrusion. Food Research International. 44(4): 1094-1101. https://doi.org/10.1016/j.foodres.2011.03. 030

Chiu, Y.T., Chiu, C.P., Chien, J.T., Ho, G.H., Yang, J., and Chen, B.H. 2007. Encapsulation of lycopene extract from tomato pulp waste with gelatin and poly (gamma-glutamic acid) as carrier. Journal of Agricultural and Food Chemistry. 55(13): 5123-5130. https://doi.org/10.1021/jf0700069

deMan, J.M. 1999. Principles of food chemistry. $3^{\text {rd }}$ ed. Gaithersburg, Maryland: Aspen Publishers, Inc.

Desai, K., and Park, H.J. 2005. Preparation of cross-linked chitosan microspheres by spray drying: effect of cross-linking agent on the properties of spray dried microspheres. Journal of Microencapsulation. 22(4): 377-395. https://doi.org/10.1080/02652040500100139

Ducel, V., Richard, J., Saulnier, P., Popineau, Y., and Boury, F. 2004. Evidence and characterization of complex coacervates containing plant proteins: application to the microencapsulation of oil droplets. Colloids and Surfaces A: Physicochemical and Engineering Aspects. 232(3): 239-247. https:// doi.org/10.1016/j.colsurfa.2003.11.001

Encina, C., Vergara, C., Giménez, B., Oyarzún-Ampuero, F., and Robert, P. 2016. Conventional spray-drying and future trends for the microencapsulation of fish oil. Trends in Food Science and Technology. 56: 46-60. https://doi.org/10.1016/j.tifs.2016.07.014

Fang, Z., and Bhandari, B. 2010. Encapsulation of polyphenols-a review. Trends in Food Science and Technology. 21(10): 510-523. https://doi.org/ 10.1016/j.tifs.2010.08.003

Flores, F.P., Singh, R.K., and Kong, F. 2014. Physical and storage properties of spray-dried blueberry pomace extract with whey protein isolate as wall material. Journal of Food Engineering. 137: 1-6. https://doi.org/10.1016/ j.jfoodeng.2014.03.034

Gharsallaoui, A., Roudaut, G., Chambin, O., Voilley, A., and Saurel, R. 2007. Applications of spray-drying in microencapsulation of food ingredients: an overview. Food Research International. 40(9): 1107-1121. https://doi.org/ 10.1016/j.foodres.2007.07.004

Gisslen, W. 2015. Essentials of professional cooking. Wiley Global Education.

Gu, X., Campbell, L.J., and Euston, S.R. 2009. Effects of different oils on the properties of soy protein isolate emulsions and gels. Food Research International. 42(8): 925-932. https://doi.org/10.1016/j.foodres.2009.04.015

Jakobek, L. 2015. Interactions of polyphenols with carbohydrates, lipids and proteins. Food Chemistry. 175: 556-567. https://doi.org/10.1016/j.food chem.2014.12.013 
Kanakdande, D., Bhosale, R., and Singhal, R.S. 2007. Stability of cumin oleoresin microencapsulated in different combination of gum arabic, maltodextrin and modified starch. Carbohydrate Polymers. 67(4): 536-541. https://doi.org/10.1016/j.carbpol.2006.06.023

Kar, S., Mukherjee, A., Ghosh, M., and Bhattacharyya, D.K. 2013. Utilization of Moringa leaves as valuable food ingredient in biscuit preparation. International Journal of Applied Science and Engineering. 1(1): 29.

Kasolo, J., Bimenya, G., and Ojok, L. 2010. Phytochemicals and uses of Moringa oleifera leaves in Ugandan rural communities. Journal of Medicinal Plants Research. 4: 753-577.

Koyoro, H., and Power, A. 1987. Functional properties of pea globulin fractions. Cereal Chemistry. 64(2): 97-101.

Li, X.R., and Tang, C.H. 2013. Influence of glycation on microencapsulating properties of soy protein isolate-lactose blends. Journal of the Science of Food and Agriculture. 93(11): 2715-2722. https://doi.org/10.1002/jsfa. 6090

Liu, S., Elmer, C., Low, N.H., and Nickerson, M.T. 2010. Effect of pH on the functional behaviour of pea protein isolate-gum arabic complexes. Food Research International. 43(2): 489-495. https://doi.org/10.1016/j.foodres. 2009.07.022

McDougall, G.J., Fyffe, S., Dobson, P., and Stewart, D. 2005. Anthocyanins from red wine their stability under simulated gastrointestinal degestion. Phytochemistry. 66: 2540-2548. https://doi.org/10.1016/j.phytochem. 2005.09.003

Oyeyinka, A.T., and Oyeyinka, S.A. 2018. Moringa oleifera as a food fortificant: recent trends and prospects. Journal of the Saudi Society of Agricultural Sciences. 17(2): 127-136. https://doi.org/10.1016/j.jssas. 2016.02.002

Paramera, E.I., Konteles, S.J., and Karathanos, V.T. 2011. Microencapsulation of curcumin in cells of Saccharomyces cerevisiae. Food Chemistry. 125(3): 892-902. https://doi.org/10.1016/j.foodchem.2010.09.063

Payet, B., Shum, C.S.A., and Smadja, J. 2005. Assessment of antioxidant activity of cane brown sugars by ABTS and DPPH radical scavenging assays: determination of their polyphenolic and volatile constituents. Journal of Agricultural and Food Chemistry. 53(26): 10074-10079. https://doi.org/10.1021/jf0517703

Ramachandran, C., Peter, K.V., and Gopalakrishnan, P.K. 1980. Drumstick (Moringa oleifera): a multipurpose Indian vegetable. Economic Botany. 34(3): 276-283. https://doi.org/10.1007/BF02858648 
Raymundo, A.,Gouveia, L., Batista, A.P., Empis, J., and Sousa, I. 2005. Fat mimetic capacity of Chilorella vulgaris biomass in oil-in-water food emulsions stabilized by pea protein. Food Research International. 38(8): 951-965. https://doi.org/10.1016/j.foodres.2005.02.016

Ruiz-Henestrosa, V.P., Sanchez, C.C., Escobar, M., Jimenez, J.J.P., Rodriguez, F.M., and Patino, J.M.R. 2007. Interfacial and foaming characteristics of soy globulins as a function of $\mathrm{pH}$ and ionic strength. Colloids and Surfaces A: Physicochemical and Engineering Aspects. 309(1): 202-215. https://doi.org/10.1016/j.colsurfa.2007.01.030

Sarwat, S., Kriti, V., and Rehan, K. 2012. Nephroprotective efficacy of chrysin against cisplatin-induced toxicity via attenuation of oxidative stress, Journal of Pharmacy and Pharmacology. 64(6): 872-881. https://doi.org/ 10.1111/j.2042-7158.2012.01470.x

Sengev, A.I., Abu, J.O., and Gernah, D.I. 2013. Effect of Moringa oleifera leaf powder supplementation on some quality characteristics of wheat bread. Food and Nutrition Sciences. 4(3): 270-275. https://doi.org/10.4236/fns. 2013.43036

Singleton, V.L., Orthofer, R., and Lamuela-Raventós, R.M. 1999. Analysis of total phenols and other oxidation substrates and antioxidants by means of folin-ciocalteu reagent. Methods in Enzymology. 299: 152-178. https:// doi.org/10.1016/S0076-6879(99)99017-1

Tumbas, Š.V., Čanadanović-Brunet, J., Ćetković, G., Jakišić, M., Djilas, S., Vulić, J., and Stajčić, S. 2016. Encapsulation of beetroot pomace extract: RSM optimization, storage and gastrointestinal stability. Molecules. 21(5): 584. https://doi.org/10.103390/molecules 21050584

Zhang, X., Chen, F., and Wang, M. 2014. Antioxidant and antiglycation activity of selected dietary polyphenols in a cookie model. Journal of Agricultural and Food Chemistry. 62(7): 1643-1648. https://doi.org/10.1021/jf4045827 